\title{
Driving Factors of Serbian Competitiveness - Digital Economy and ICT
}

\author{
Ivana Domazet \\ Institute of Economic Sciences, Belgrade, Serbia \\ Jovan Zubović \\ Institute of Economic Sciences, Belgrade, Serbia \\ Milena Lazić \\ Belgrade Banking Academy, Belgrade, Serbia
}

\begin{abstract}
One of the major challenges for policymakers in Serbia is to improve the competitiveness of the Serbian economy. Universally applicable solution to this problem does not exist, but there are certain segments which can be a significant driver of improving the effectiveness and productivity of the economy by implementing diverse possibilities offered by the digital economy. A critical factor in the development of digital economy is the sector of information and communication technology (ICT), which has the potential to extremely improve the competitiveness of Serbia and start production towards modern business processes, but also contribute to a notable synergistic effect in terms of the competitiveness of micro-enterprises. Accordingly, the aim of this paper is to highlight the importance of information and communication technologies (ICT) as a factor for competitiveness and development of the digital economy, to analyze the application of ICT in the economy of Serbia, to highlight the benefits of development and acceptance of new solutions in the field of ICT, to create recommendations that would contribute to improving the business environment in the ICT field, and consequently of the digital economy as a whole.
\end{abstract}

\section{Keywords}

Digital economy, competitiveness, information and communication technologies (ICT), business environment, development.

\section{Introduction and literature review}

Serbian economy, being underdeveloped and yet transitional economy, requires modern ICT solutions. Only significant investment in the ICT sector and the development of ICT can encourage creation of a strong economy based on knowledge ad information technologies. With that regard, the aim of this paper, based on the analysis of the degree of development of ICT in Serbia, is to create guidelines and give recommendations on how to improve the business environment and intensify the development of ICT in Serbia. The methodology used in this paper is based on the analysis of the indicator of Innovativeness and application of new technologies index by the World Economic
Forum and empirical research on the degree of implementation of new technologies in enterprises Serbia. The survey was conducted in the period January-March 2017 and the survey sample consisted of 87 Serbian companies, classified as medium and large businesses. The survey results indicate a low level of information and communication development in enterprises in Serbia in the field of implementation of modern ICT, as confirmed by the evaluation of the World Economic Forum on the competitiveness of Serbia in the segment of sophistication of business processes and, consequently, innovation in business. ICT development is a necessary precondition for the economy based on the implementation of new 
technologies and the relatively low level of ICT development in Serbia should not be seen as a constraint, but rather as an opportunity for further improvement. In order to take advantage of the ICT potential, it is necessary to increase investment in this highly productive sector and encourage the production and sale of domestic ICT products, either through tax reliefs to companies from the ICT sector, or through various forms of subsidies when purchasing domestic ICT products. In addition, it is crucial to impose appropriate educational policies, such as to increase the enrolment quotas for students of electrical, mechanical, technological and other related orientation relevant to the development of ICT.

Ten years after the outbreak of the world economic crisis, its effects are still notable. The recovery of world economies is slower than expected, while global factors of instability (such as crisis in Ukraine, the conflicts in the Middle East, terrorism, migrant crisis) further contributed to the reduction in economic activity in countries around the world. Accordingly, in recent years more attention is paid to following up and analyzing the factors affecting the improvement of competitiveness of world economies.

The importance of following up macro competitiveness (competitiveness analyzed in terms of the economy as a whole) at the global level is best emphasized by a large number of published empirical studies referring to that issue. In this regard, the European Commission in its European Competitiveness Report examines the basic performance of the competitiveness of the EU as a whole, member states, or certain economic activities, while the WEF (World Economic Forum) affirmed the GCI - Index (Global Competitiveness Index) for following up basic indicators of competitiveness of countries around the world. Within individual studies, however, the competitiveness of the economies is not evaluated directly, but from the point of view of specific factors affecting the improvement of competitiveness. Well-known studies include The Ease of Doing Business (World Bank), Index of Economic Freedom (Heritage Foundation) or progress in transition (EBRD). On the other hand, in a number of empirical studies emphasis is placed on the analysis of conditions for the development and improvement of social and intellectual capital and innovation as key factors for the acquisition of long-term competitive advantage on a global level (Gonzales-Pernia, Pena-Legazkue, \& Vendrell-Herrero, 2012, ), while the authors such as Ambec, Cohen,
Elgie and Lana (Ambec, Cohen, Elgie, \& Lano, 2013), as well as Brosseau and Penard (Brousseau \& Penard, 2016) in their studies investigated the characteristics of the economic environment which mostly contribute to economic development of the specific country. To support that idea, a number of Serbian authors (Domazet, Stosic, \& Hanić, 2016; Stosic \& Domazet, 2014; Anđelić, Brnjas, Domazet, 2016; Zubović \& BradićMartinović, 2014) divide competitiveness factors into two basic categories - microeconomic and macroeconomic pointing out that low competitiveness of the Serbian economy is to a large extent the result of delayed transition, isolation from the world market for many years, long-term disinvestment and technological lagging behind the developed economies (Paraušić, Domazet, \& Simeunović, 2018). Finally, the improvement of skills in the field of innovation, information and communication technologies and the development of sustainable innovative activities that improve competitiveness and contribute to the development of the digital economy are subjects of investigation of a large number of research studies (Boons, Montalvo, Quist, \& Wagner, 2013; Carayannis \& Grigoroudis, 2012; Carayannis, Grigoroudis, Sindakis, \& Walter, 2014; Proskuryakova, Meissner, \& Rudnik, 2015; Domazet, 2016), while the importance of the digital economy for economic development was the theme of the papers of authors such as Kehal and Singh (Kehal \& Singh, 2004), Espinel (Espinel, 2016). Considering that in the modern business environment ICT become the most important driver of innovation, growth and competitiveness, and a source of new business opportunities, this paper particularly analyzes the use of ICT in companies doing business in Serbia, since ICT makes the basis for the development of the digital economy (Domazet \& Neogradi, 2018).

The digital economy is an economy based on digital technologies and the primary use of information technology hardware, software, applications and telecommunications in all areas of economy, including internal activities of organizations (companies, government, associations, non-profit organizations, etc.), then external activities (various transactions) between the organizations, between organizations and individuals, as well as individuals among each other (individuals as consumers and citizens). The digital economy is at the same time the knowledge based economy, because it is essentially based on professional and market knowledge, creativity and innovation soci- 
ety as a whole. Speaking broadly, the digital economy represents a strategic guideline of the modern society and state in the 21 st century. The digital economy means a shift in thinking, i.e. the transition from conventional development methods that are typical for the state economies to the dynamic development models which are based on continuous improvement and development. Some authors claim (Vidas-Bubanja \& Bubanja, 2015) that the digitalization as a process is not only a supplement to existing business processes, but to a complete change in the organizational structure and culture, that is a change in the way of thinking of the organization.

The key factor in the development of the digital economy is certainly the implementation and development of modern ICT solutions. Recognizing the importance of monitoring the speed of implementation of modern ICT solutions, since 2001, the World Economic Forum has published a report in which it follows up the Networked Readiness Index for all the countries of the panel. Within the index key indicators are studied that are grouped into three categories - overall environment, the ability to use ICT, the impact that ICT has on the economy and society a specific country. The development of microelectronics, production and use of computers enabled the transition from the industrial towards the information society (Ćuzović \& Sokolov-Mladenović, 2014; Savić \& Zubović, 2015). The application of digital technologies allows all companies, including SMEs, to render services cheaply to a large number of consumers which directly affects the growth of competitiveness of the observed economy. Concerning that, the subject of this paper is the analysis of the situation and the level of development of ICT sector in Serbia. The paper aims to highlight the importance of information and communication technologies (ICTs) as a factor of competitiveness and development of the digital economy, to analyze the application of ICT in the Serbian economy, to highlight the benefits of development and acceptance of new solutions in the field of ICT and to make recommendations that would contribute to the improvement of the business environment in the field of ICT, and consequently the digital economy as a whole. The methodology used in this paper is based on the analysis of sub-index factors such as Innovation and sophistication factors within the Global Competitiveness Index published by the World Economic Forum, as well as the results obtained on the basis of the empirical study of the degree of implementation of new technologies in Serbian enterprises. The research was conducted in the period September-December 2017, and a survey sample consisted of 96 companies operating in Serbia, which are classified as medium and large companies.

The paper consists of four parts. After introductory considerations and review of literature, the key dimensions of development of ICT sector in Serbia are analyzed in the second part as well as the degree of use of ICT by companies operating in Serbia. The third part explains the potential sources of growth of ICT in Serbia and gives guidelines for further improvement of business of ICT companies in Serbia. The fourth part brings about final consideration with recommendations for the creation of supportive public policies in the field of ICT.

\section{Research results of the development of ICT market in Serbia}

In this part of the paper, the results of secondary and primary research of the authors are gathered, in order to determine the level of development of Serbia in comparison to other EU countries. In fact, numerous empirical studies confirm a positive link between the development of the economy and investment in the ICT sector. In other words, developed countries have recognized the potential for investment in the ICT sector in terms of further progress and growth of macro competitiveness, and investments of these countries in the ICT sector are significant compared to the amount of funds which less developed countries allocate for these purposes.

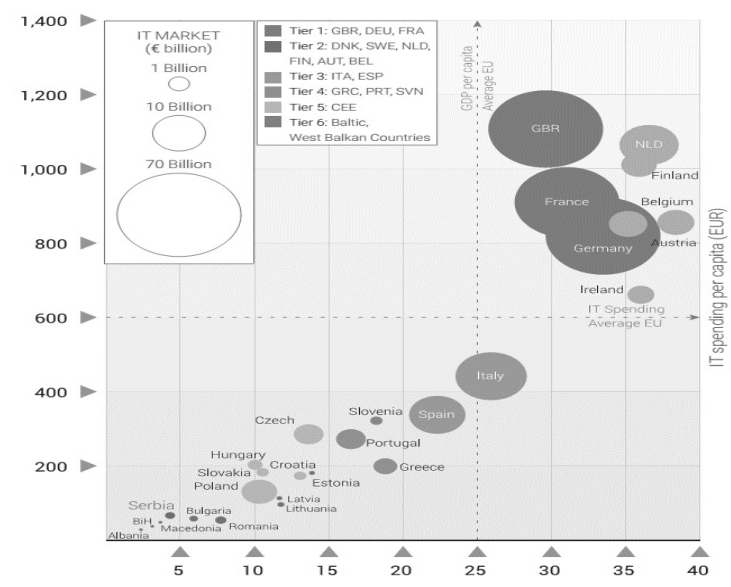

Figure 1 Clusterisation of European countries according to the level of investment in IT sector (measured by IT investments per capita) and the degree of development (measured by GDP per capita)

Source: Vojvodina ICT cluster, 2016 p. 19 
Figure 1 indicates the way in which the European countries are grouped in 6 categories (clusters) as seen through observation of two parameters - IT spending per capita and GDP per capita. Prior to analyzing the results presented in Figure 1 it is important to point out the robustness of the clusters in case of the alteration of data for the whole observed period (2007-2015). Analyzing data presented in Figure 1 it can be noted that the panel of the analyzed European countries can be divided into six main groups. In the first and second group are the most developed countries of Western and Northern Europe, which are characterized by a high level of investment in the ICT sector. In the third and fourth group entail Mediterranean countries which are characterized by a high level of GDP per capita and low levels of investment in the ICT sector. In the fifth group there are 10 EU countries that have recently joined the EU which are characterized by low levels of GDP per capita and low levels of investment in the ICT sector. Finally, the sixth group includes countries with low ICT market as well as the Baltic countries.

According to the findings published within the study of the World Economic Forum (WEF), the acceptance of ICT, infrastructure and innovation system in our country are still at inadequate level. Specifically, according to index published by this organization (Networked Readiness Index) Serbia in 2015 was at $77^{\text {th }}$ position out of 143 countries. According to the World Economic Forum, our country is lagging behind mostly in the field of ICT in companies' business (125th place) and political and legal environment (110th). Ranking Serbia according to key parameters which are studied in the World Economic Forum report is presented in Table 1.

Table 1 Networked Readiness Index for Serbia, 2015

\begin{tabular}{|l|c|c|}
\hline & $\begin{array}{c}\text { Rank } \\
\text { (out of 143) }\end{array}$ & $\begin{array}{c}\text { Value } \\
(1-7)\end{array}$ \\
\hline Network Readiness Index 2015 & 77 & 4.0 \\
\hline $\begin{array}{l}\text { Network Readiness Index 2014 } \\
\text { (out of 148) }\end{array}$ & 80 & 3.9 \\
\hline $\begin{array}{l}\text { Network Readiness Index 2013 } \\
\text { (out of 144) }\end{array}$ & 87 & 3.7 \\
\hline A. Environment subindex & 100 & 3.6 \\
\hline $\begin{array}{l}\text { 1st pillar: Political and regulatory } \\
\text { environment }\end{array}$ & 110 & 3.1 \\
\hline $\begin{array}{l}\text { 2nd pillar: Business and } \\
\text { innovation environment }\end{array}$ & 84 & 4.1 \\
\hline
\end{tabular}

\begin{tabular}{|l|c|c|}
\hline B. Readiness subindex & 48 & 5.2 \\
\hline 3rd pillar: Infrastructure & 42 & 4.8 \\
\hline 4th pillar: Affordability & 61 & 5.5 \\
\hline 5th pillar: Skills & 66 & 5.1 \\
\hline C. Usage subindex & 80 & 3.7 \\
\hline 6th pillar: Individual usage & 55 & 4.6 \\
\hline 7th pillar: Business usage & 126 & 3.0 \\
\hline 8th pillar: Government usage & 111 & 3.3 \\
\hline D. Impact subindex & 89 & 3.4 \\
\hline 9th pillar: Economic impacts & 80 & 3.1 \\
\hline 10th pillar: Social impacts & 90 & 3.7 \\
\hline
\end{tabular}

Source: The authors' review based on the World Economic Forum, 2015.

The World Economic Forum (WEF) for the year 2015 positioned Serbia at the $94^{\text {th }}$ place on the list of 140 countries with the Global Competitiveness Index 3.89. When the above indicator is compared with those achieved in 2014, we see a slight decline in the Global Competitiveness Index of 0.01 with unchanged ranking of our country in this list.

Global Competitiveness Index of the World Economic Forum is based on twelve factors that are grouped into three categories. The first category consists of the basic requirements including the following parameters: institutions, infrastructure, macroeconomic stability, health and primary education. The second category involves factors to increase efficiency: higher education and training, goods market efficiency, labor market efficiency, financial market sophistication, technological readiness and market size. The third category consists of two factors: sophistication of business processes and innovations. Macro competitiveness of national economy is determined by analyzing the above factors and forming of the average rating.

Table 2 shows the evaluation of factors of global competitiveness of our country in the period 2013-2015. The group of factors relating to innovation and application of new technologies represents a group of the factors which are assessed as the weakest, which speaks in favor of the hypothesis about the insufficient level of development of the domestic ICT market, i.e. the potential and the need for its further improvement. 
Table 2 Factors of global competitiveness of Serbia evaluation for the period 2013-2015

\begin{tabular}{|c|c|c|c|}
\hline Subindex: Basic Requirements & 2013 & 2014 & 2015 \\
\hline 1. Institutions & 3,20 & 3,21 & 3,24 \\
\hline 2. Macroeconomic Environment & 3,36 & 3,51 & 3,61 \\
\hline 3. Infrastructure & 3,51 & 3,39 & 3,87 \\
\hline 4. Health and Primary Education & 5,75 & 5,76 & 5,87 \\
\hline $\begin{array}{l}\text { 5. Higher Education and } \\
\text { Training }\end{array}$ & 4,05 & 4,25 & 4,27 \\
\hline Subindex B: Efficiency enhancers & 2013 & 2014 & 2015 \\
\hline 6. Goods Market Efficiency & 3,64 & 3,78 & 3,74 \\
\hline 7. Labor Market Efficiency & 3,90 & 3,73 & 3,72 \\
\hline $\begin{array}{ll}\text { 8. } & \text { Financial Market } \\
\text { Development }\end{array}$ & 3,48 & 3,50 & 3,23 \\
\hline 9. Technological Readiness & 3,94 & 4,45 & 4,47 \\
\hline 10. Market Size & 3,68 & 3,68 & 3,70 \\
\hline $\begin{array}{l}\text { Subindex C: Innovations and } \\
\text { sophistication factors }\end{array}$ & 2013 & 2014 & 2015 \\
\hline 11. Innovation & 2,85 & 2,89 & 2,90 \\
\hline 12. Business Sophistication & 3,18 & 3,21 & 3,14 \\
\hline
\end{tabular}

Source: Authors' review based on data published in the World Economic Forum, 2015

Taking into consideration the importance of the use of information and communication technologies in business to improve macro competitiveness of the national economy, collection of primary data was conducted through empirical research on the use of modern ICT in Serbia. The research was conducted in the period SeptemberDecember 2017. The sample consisted of 96 small and large-sized companies operating in Serbia. The method used for data collection is telephone interview and the respondents replied to questions from the questionnaire structured in advance on the degree of implementation of new technologies in their enterprise. The main findings of the research indicate the following:

- $96 \%$ of companies use computers and have access to the Internet

- $76 \%$ of companies have their web site

- $39 \%$ of companies order products on-line

- $24 \%$ of companies receive orders on-line

- $27 \%$ of companies maintain their ICT infrastructure

- $21 \%$ of companies employs an IT expert

- $9 \%$ of companies use cloud services

- $7 \%$ of companies have developed ERP and CRM systems.

Findings point to an extremely low level of information and communication development of domestic enterprises in the field of implementation of modern ERP and CRM systems, as confirmed by the evaluation of the World Economic Forum on the competitiveness of Serbia in the segment of the sophistication of the business process and, consequently, innovation in business. One of the major problems which affect the low level of competitiveness of Serbian companies is the insufficient implementation of the CRM system within the business processes of enterprises (Domazet, Lazic, \& Simovic, 2014, p. 620). The CRM (Customer Relationship Management) is the process of developing and managing relationships with consumers. Adequate implementation of CRM contributes to a higher level of customer satisfaction, which is a precondition for their greater loyalty and, consequently, greater profitability of service companies. However, the use of the CRM concept requires the use of relatively sophisticated information technologies, including the innovative designs of modern information architecture, database, data management with modern software, statistical and IT tools (Domazet \& Zubovic, 2011, p. 405). Consequently, it is necessary to reposition the companies in this sector so as to provide Serbia the role of the regional leader in attracting foreign direct investment, especially in the field of ICT, which requires greater government assistance. This is supported by the development of science and science and technology parks, as well as the association of ICT companies in the cluster in order to increase market power. Regarding the investments in the ICT sector, Serbian companies invest about $0.5 \%$ of total revenues, which is significantly below the amount invested by international companies, especially if we take into account the amount of income of domestic companies in an absolute sense. The situation is similar when it comes to the number of employees - Serbian companies employ four times fewer IT experts compared to IT companies operating in developed market economies. In terms of regional distribution of ICT companies, most of them are located in Belgrade, Novi Sad and Niš.

\section{Potentials and Sources of Growth of ICT in Serbia}

Apart from the sector of education, IT sector is recognized by the state as being important for economic development and improvement of domestic macro competitiveness. Regarding that, in December 2016, the Serbian Government adopted the Strategy for development of information technology industry for the period from 2017 to 2020 with the aim of strengthening the technological ecosystem in Serbia. The Act defined that the main strategic priorities in the future would be the following: 
- development of successful companies and products in the field of IT

- improvement of administrative environment suitable for development of IT industry

- building up human resources potentials

- modernization of business in all branches through the use of IT. (Vlada Republike Srbije, 2016)

In accordance with the defined strategic priorities for the upcoming period, the Strategy defined measures in the following areas: support to IT entrepreneurship and start up projects; tax incentives; support to exporters; support to IT application for the purpose of modernization of business in all industry branches; improvement of legal framework; Improvement of human resources potentials; promotion of Serbian IT industry.

The state has so far been an important factor in the development of the domestic IT industry, although it is not positioned as a partner in the IT sector. Although there are 35 state-owned ICT institutions of higher education where each year around 5500 freshmen enrol $80 \%$ of which study at the expense of the budget of the Republic of Serbia, the IT sector has only recently started to recognize the role of the state in the provision of the necessary personnel (Domazet, Lazic \& Simovic, 2014). The increase in the number of students enrolled at the IT oriented faculties is the result of the growth of the popularity of the IT profession among young people. Due to that more should be done to increase the capacity of the IT oriented faculties. In addition, the study programs should be harmonized with the practical needs, i.e. more should be done on strengthening and intensifying cooperation between three groups of subjects - faculties and other institutions of higher education, scientific research institutions and IT companies.

On the domestic IT market there is a visible trend of creating science and technology parks and clusters as well as the specific forms of cooperation between local IT companies. With regards to that, there are three large ICT clusters in Serbia - Vojvodina ICT Cluster, Niš ICT cluster and the Central Serbia ICT cluster - Kragujevac. In addition, for several years now the scientifictechnological park Zvezdara has been operating successfully, i.e. business-technology incubator of technical faculties of Belgrade. These trends, which have been notable in recent years in the domestic ICT sector, will contribute to better visi- bility and better regional positioning of our country on the world technology map. By creating clusters, companies spread the network of contacts and generate additional benefits. In addition to the development of science and technology parks, Serbian IT companies increase their visibility and attractiveness in the international market by promoting and launching their own original solutions in this area. Accordingly, our country is globally recognized as a very attractive alternative location for the development of sophisticated software, and domestic IT companies are identified as entities that possess the necessary knowledge, experience and resources to provide outsourcing services of high quality.

One of the basic conditions for the creation and development of innovative solutions in the field of ICT is an easier access to the capital necessary to finance research and development in these companies. In the study published by the Vojvodina ICT cluster (Vojvodina ICT cluster, 2015) the main reasons are summarized for the growth of investments in the IT industry even in times of crisis:

- IT infrastructure is an important precondition for development of economy and society;

- In order to get involved in the global market, IT industry requires a significantly fewer resources in comparison to other industries;

- IT industry is considerably cheaper, but more profitable than other industries;

- Development of ICT industry contributes to reducing the 'brain drain' phenomenon.

The capital is necessary in the initial stages of development of innovative companies so as they could develop and perfect a new product, but also to ensure its placement on the global market. Such investments by groups or funds in the initial stages of development companies or projects (i.e. business angels) has enabled companies and projects such as Google, Amazon, YouTube or eBay to reach current leading position in the global market. For these investors, the investments in the ICT sector are the most attractive as there is the largest number of innovative projects that can be easily and simply distributed to international markets. With regards to that, the activities of the country in the future should focus on informing and educating companies about the possibilities of finding alternative ways of financing innovative projects. This activity would greatly contribute to 
the growth and development of local ICT companies, as well as the increase in exports and improvement of competitiveness of the domestic economy.

Serbian Chamber of Commerce gives great contribution to the development of ICT in Serbia through the Association for Electronic Communications and Information Society. The association continuously organizes meetings, seminars and conferences in order to promote the development of the ICT industry in Serbia starting from the assumption that the concept of optimal ICT programs at the national level is possible only if the process involves domestic IT companies which are very familiar with 'the on-site situation'. In accordance with that, formal and informal communication has been established with more than 1000 relevant IT experts from almost all companies with programming capabilities (Privredna komora Srbije, 2016). In order to get relevant feedback, in 2016 the electronic survey was conducted, responded by over 200 experts from leading programming companies operating in Serbia. Analyzing the results of the conducted survey the following findings have been elicited:

- Lack of awareness of policy makers on the potential growth of the domestic IT sector.

- Poor communication channels between companies operating in the IT sector and domestic economic policy makers.

- Extremely high operating costs of firms in this sector, as well as high tax obligations to the state. The measure which in recent years had the greatest negative impact on the business of domestic IT companies, which entered into force on 1 January 2014, is certainly the increase in the VAT rate from $8 \%$ to $20 \%$ (in 2007 VAT lowered from $18 \%$ to $8 \%$ ).

- The dominant share of SMEs in the IT market and their inability in large IT projects, i.e. obtaining significant reference.

- Professional staff moving abroad.

- The need to modernize the curriculum and increase enrolment quotas for IT studies.

The main results of the implemented SWOT analysis in the domestic IT market show that domestic economy and public services use ICT resources in organization and optimization of their work processes insufficiently. Regarding application of e-commerce and the use of the Internet, the SME sector in Serbia is far behind the majority of the EU member states. The most common form of the Internet usage in companies doing business in our country refers to e-banking and e-payment, while e-commerce is still underrepresented. According to data published by Statistical Office of the Republic of Serbia (Republički zavod za statistiku, 2016), in 2014 only $40.3 \%$ of companies in Serbia ordered goods and services over the Internet, while the percentage of those which received orders via the internet in 2014 is significantly smaller and amounts to $22.9 \%$. Internet as a sales and communication channel with key stakeholders is of special importance for small and medium-sized enterprises which are often focused on a specific market niche, while large sales networks are not so available to them. Key activities to support the introduction of e-business and ecommerce in these companies involve education of the management and financial assistance aimed at strengthening the capacity for the introduction of electronic commerce.

National market still represents one of the greatest potentials for IT companies operating in Serbia. Taking into account that Serbia is still an economy in transition, it is not surprising that domestic companies use outdated technology to a large extent. In addition, further improvement of business increases awareness of the use of new, more modern IT solutions in further operations. On the other hand, the future modernization of state activities is another great potential and incentive for Serbian IT companies.

\section{Concluding remarks and recommendations}

ICT sector in Serbia, although insufficiently developed for intensive development of the digital economy, has significant potential. Given that the domestic economy requires modern ICT solutions, but also the fact that the ICT sector accounts for an engine of development of economies of developed countries, the more significant role of the state in the assistance to the domestic ICT sector in the future is essential. With regards to that, closer cooperation between the ICT sector, the education sector and the private sector would enable the creation of synergy effect from which all would benefit. Namely, in the next period the emphasis should be put on the education of IT experts, modernization of the education system, as well as the employment of graduates in companies doing business in Serbia. Below are recommendations regarding the sequence of actions to support the development of the domestic ICT sector: adjusting the education system with the needs of the 
IT industry; modernization of curriculum and increasing enrolment quotas for IT studies; introducing tax incentives that encourage investments in the IT sector; different types of support to domestic exporters of software; subsidies for startups in the IT sector; subsidies for end users to purchase equipment and software.

Along with that, recommendations which could improve business environment in ICT sector are the following:

1. To establish a center which would be the leader of association and information towards clusters and small companies engaged in IT sector and which would recognize good ideas, filter them and further support their development, i.e. formation of Information technology chamber of Serbia as an umbrella association in ICT industry.

2. To create a portal and domestic companies index (e.g. LinkedIn group for local cooperation) with the aim to join small-sized companies to participate together in competitive bidding abroad. Experience basis on foreign markets and interpretation of local regulations.

3. Organizing cooperation of domestic companies and educating managers so that domestic IT companies can liaise with foreign markets.

4. Developing strategic plans for the assistance to small-sized companies in IT sector, organizing joint promotion and providing grants for small IT companies.

5. Organizing an IT association which would be engaged in launching domestic IT products and services at the international market in the form of an intermediary between buyers and small-sized IT companies which do not have enough resources and possibilities to establish procedure independently and follow the process logistically.

6. Increasing the visibility of Serbia as the ICT destination and more intensive support of state in selling/advocating in ICT industry.

Finally, taking into account the insufficient use of modern ICT technologies in companies that do business in Serbia, as well as a clear commitment of the state in terms of intensive implementation of e-governance and digitalization of business processes, it can be said that the national market continues to represent one of the greatest growth potential for domestic IT companies.

\section{Acknowledgment}

This paper is written as a part of the research projects III47009 (European Integrations and Social and Economic Changes in Serbian Economy on the Way to the EU) and OI179015 (Challenges and Prospects of Structural Changes in Serbia: Strategic Directions for Economic Development and Harmonization with EU Requirements), financed by the Ministry of Education, Science, and Technological Development of the Republic of Serbia. sm

\section{References}

Ambec, S., Cohen, M., Elgie, S., \& Lanoie, P. (2013). The Porter hypothesis at 20: Can environmental regulation enhance innovation and competitiveness? Review of Environmental Economics and Policy, 7 (1), 2-22.

Anđelić, S., Brnjas, Z., \& Domazet, I. (2016). Education and entrepreneurship, In L. Zanadu, et al. (Eds.) Insights and potential sources of new entrepreneurial growth (pp. 383-393). Bologna: Filodiritto Publisher Inforomatica.

Boons, F., Montalvo, C., Quist, J., \& Wagner, M. (2013). Sustainable innovation, business models and economic performance: an overview. Journal of Cleaner Production, 45, 1-8.

Brousseau, E., \& Penard, T. (2016). The economics of digital business models: A framework for analyzing the economics of platforms. Review of Network Economics, 6 (2), 81-110

Carayannis, E. G., Grigoroudis E., Sindakis S., \& Walter C. (2014). Business Model Innovation as antecedent of sustainable enterprise excellence and resilience. Journal of the Knowledge Economy, 5 (3), 440-463.

Carayannis, E. G., \& Grigoroudis, E. (2012). Linking innovation, productivity and competitiveness: Implications for policy and practice. Journal of Technology Transfer, 39 (2), 199-218.

Ćuzović, Đ., \& Sokolov-Mladenović, S. (2014). Globalizacija i digitalna ekonomija. Sinteza 2014, 143-147.

Domazet, I., \& Neogradi, S. (2018). Digital Marketing and Service Industry: Digital Marketing in Banking Industry. In N. Ray (Ed.), Monograph Managing Diversity, Innovation, and Infrastructure in Digital Business, Hershey: IGI Global.

Domazet, I. (2016). Unapređenje konkurentnosti preduzeća implementacijom CRM modela, In J. Minović et al. Pravci strukturnih promena u procesu pristupanja Evropskoj Uniji, (pp. 225-241).

Domazet, I., \& Zubović, J. (2011). Database marketing based business development: the case of Serbian financial sector. In Šalej et al. (Eds.), Contemporary issues in the integration processes of Western Balkan countries in the European Union (pp. 399-414), Ljubljana: International Center for Promotion of Enterprises.

Domazet, I., Lazić, M., \& Simović V. (2014). Mogućnosti i pretpostavke za razvoj IKT industrije u Srbiji. B. Drašković (Ed.), Deindustrijalizacija u Srbiji: mogućnost 
revitalizacije industrijskog sektora, (pp. 619-637),

Beograd: Institut ekonomskih nauka.

Domazet, I., Stošić, I., \& Hanić, A. (2016). New technologies aimed at improving the competitiveness of companies in the services sector. In X. Richet et. al. (Eds.), Europe and Asia: Economic Integration Prospects (pp. 363-377), Nice: CEMAFI.

Espinel, V. A. (2016). The digital economy: what is it and how will it transform our lives? Retrieved December 17 2017, from https://www.weforum.org/agenda/2016/11/the-digitaleconomy-what-is-it-and-how-will-it-transform-our-lives/.

Gonzalez-Pernia, J. L., Pena-Legazkue, \& Vendrell-Herrero F. (2012). Innovation, entrepreneurial activity and competitiveness at a sub-national level. Small Business Economics, 39 (3), 561-574.

Kehal, H. S., \& Singh, V. P. (2004). Digital economy: impacts, influences and challenges. Hershey: Idea Group Publishing.

Paraušić, V., Domazet, I., \& Simeunović, I. (2017), Analysis of the Relationship Between the Stage of Economic Development and the State of Cluster Development, Argumenta Oeconomica, 39 (2), 279-305.

Privredna komora Srbije, (2015). Analiza IT sektora Srbije. Beograd: Privredna komora Srbije.

Proskuryakova, L., Meissner, D., \& Rudnik P. (2015). The use of technology platforms as a policy tool to address research challenges and technology transfer. Retrieved December 18, 2017 from SpringerLink: http://link.springer.com/article/10.1007/s10961-0149373-8\#/page-1.

\section{$\triangle$ Correspondence}

\section{Ivana Domazet}

Institute of Economic Sciences

Zmaj Jovina 12, 11000, Belgrade, Serbia

E-mail: ivana.domazet@ien.bg.ac.rs
Republički zavod za statistiku (2016). Upotreba informaciono komunikacionih tehnologija u Srbiji. Beograd: Republički zavod za statistiku.

Savić, M., \& Zubović, J. (2015). Comparative analysis of labour markets in South East Europe. Procedia economics and finance, 22, 388-397.

Stošić, I., \& Domazet, I. (2014). Analiza konkurentnosti poslovanja i potencijali rasta privrede Srbije u periodu svestke krize, Teme, 38 (2), 491-506.

Vidas-Bubanja, M., \& Bubanja, I. (2015). ICT as prerequisite for economic growth and competitiveness case study print media industry. Journal of Engineering Management and Competitiveness, 5 (1), 21-28.

Vlada Rebublike Srbije (2016). Strategija razvoja industrije informacionih tehnologija za period od 2017. do 2020 . godine br. 95/2016 Beograd: Službeni glasnik.

Vojvodina ICT cluster (2016). ICT at Serbia - At a glance 2015. Retrieved December 5, 2017 from http://vojvodinaictcluster.org/wpcontent/uploads/2014/08/ICT-in-Serbia-At-a-Glance2015.pdf.

World Economic Forum (2015). Reports for period 20072015. Retrieved December 10, 2017 from https://www.weforum.org/reports

Zubović, J., \& Bradić-Martinović, A. (2014). Competitiveness of Nations in selected SEE Countries. Procedia Economics and Finance, 8, 755-762.. 